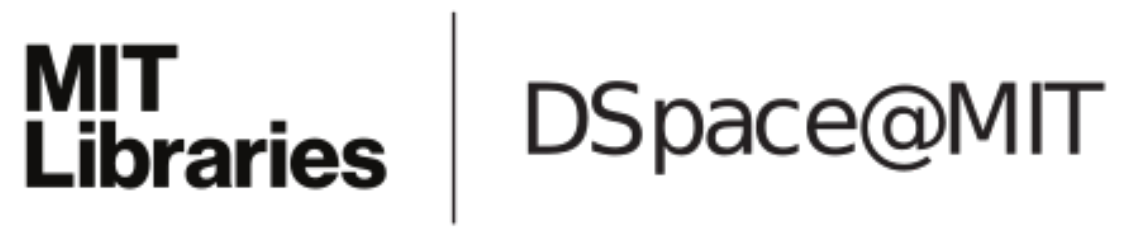

\author{
MIT Open Access Articles
}

Impact of deforestation on solid and dissolved organic matter characteristics of tropical peat forests: implications for carbon release

The MIT Faculty has made this article openly available. Please share how this access benefits you. Your story matters.

Citation: Gandois, L., A. R. Cobb, I. Chieng Hei, L. B. L. Lim, K. Abu Salim, and C. F. Harvey. "Impact of Deforestation on Solid and Dissolved Organic Matter Characteristics of Tropical Peat Forests: Implications for Carbon Release." Biogeochemistry 114, no. 1-3 (October 29, 2012): 183-199.

As Published: http://dx.doi.org/10.1007/s10533-012-9799-8

Publisher: Springer Netherlands

Persistent URL: http://hdl.handle.net/1721.1/107129

Version: Author's final manuscript: final author's manuscript post peer review, without publisher's formatting or copy editing

Terms of use: Creative Commons Attribution-Noncommercial-Share Alike 


\title{
Impact of deforestation on solid and dissolved organic matter characteristics of tropical peat forests: implications for carbon release
}

\author{
L. Gandois • A. R. Cobb $\cdot$ I. Chieng Hei • \\ L. B. L. Lim • K. Abu Salim • C. F. Harvey
}

Received: 3 March 2012/ Accepted: 18 September 2012/Published online: 29 October 2012

(C) Springer Science+Business Media Dordrecht 2012

\begin{abstract}
This study compares the organic chemistry of peat beneath one of last remaining pristine tropical peat forests in Southeast Asia with a neighbouring peat dome that has been deforested, but not intentionally drained, in the Belait district of Brunei Darussalam, Borneo. We characterized the solid and dissolved organic matter collected from the two domes, through a combination of methods including elemental analysis, phenolic content and Fourier transform infrared spectroscopy (FTIR) investigation of solid peat, as well as optical characterisation (absorbance, fluorescence) of dissolved organic matter (DOM). The peat had a high content of lignin, consistent with its origin from the Shorea albida trees on the domes. Dissolved organic carbon (DOC) concentration in the pore water was
\end{abstract}

L. Gandois $(\bowtie)$ · A. R. Cobb · C. F. Harvey

Singapore-MIT Alliance for Research and Technology,

3 Science Drive 2, Singapore 117543, Singapore

e-mail: laure.gandois@smart.mit.edu

I. C. Hei · L. B. L. Lim

Chemistry Programme, Universiti of Brunei Darussalam,

Bandar Seri Begawan BE1410, Brunei Darussalam

K. A. Salim

Biology Programme, Universiti of Brunei Darussalam,

Bandar Seri Begawan BE1410, Brunei Darussalam

C. F. Harvey

Ralph M. Parsons Laboratory,

Department of Civil \& Environmental Engineering,

Massachusetts Institute

of Technology, Cambridge, MA 01239, USA significantly greater in the deforested site $(79.9 \pm$ $\left.5.5 \mathrm{mg} \mathrm{l}^{-1}\right)$ than the pristine site $\left(62.2 \pm 2.2 \mathrm{mg} \mathrm{l}^{-1}\right)$. The dissolved organic matter was richer in nitrogen and phenolics in the deforested site. The optical properties (Fluorescence Index) indicated a modification of DOM cycling in the deforested site (enhanced decomposition of the peat and fresh litter). Comparison of the solid peat composition between the two sites also suggests effects of deforestation: sulphur, nitrogen and phenolic contents were higher in the deforested site. Taken together, these observations are consistent with peat enhanced decomposition in the deforested site, even without engineered drainage.

Keywords Tropical peatland $\cdot$ Logging $\cdot$ DOC . Nitrogen · FT-IR · UV-Vis · Fluorescence

\section{Introduction}

Tropical peatlands, unlike temperate and northern peatlands, are mostly forested (Anderson, 1983; Rieley 2008). Most tropical peat forests are located in South East Asia. The overall rate of deforestation in South East Asia is estimated to be $1 \%$ per year (Miettinen et al. 2011), and this rate is higher on peatlands compared to non peatland areas (Hooijer 2006). Exploitation of peat forests ranges from selective logging (Kobayashi 1999) to complete deforestation, drainage and conversion to acacia and palm tree plantations (Hooijer et al. 2010). 
Tropical peatlands store a huge quantity of organic carbon, estimated to be $88.6 \mathrm{Gt}$ total carbon mass. South East Asia contains $\sim 77 \%$ of the carbon stored in all tropical peatlands, an amount equal to 11-14\% of the total pool of carbon stored in all peat (Page et al. 2011a). Deforestation, drainage, and burning of these peatlands are releasing massive fluxes of $\mathrm{CO}_{2}$ to the atmosphere (Page et al. 2002; Jauhiainen et al. 2005 Hirano et al. 2009; van der Werf et al. 2009; Couwenberg et al. 2010; Hergoualc'h et al. 2011; Page et al. 2011b). Deforestation has both direct and indirect impact on carbon stocks and fluxes in terrestrial ecosystems (Bala et al. 2007). In addition to the decrease of above and below ground biomass (Hergoualc'h et al. 2011), the removal of forest canopy decreases interception of atmospheric moisture and increases solar radiation inputs and hence temperature at the soil surface (Hoffmann 2003; Jauhiainen et al. 2012). Decomposition of slash from logging often releases a flush of nutrients to the soils (Kreutzweiser et al. 2008). These conditions likely stimulate microbial activity, thereby altering rates of organic matter decomposition and inducing carbon release as $\mathrm{CO}_{2}$ to the atmosphere and dissolved organic carbon to rivers. Forested peatlands are thought to be more sensitive to deforestation than mineral forests (Nieminen 2004) because of their low nutrient content and sensitivity to water table level.

The most obvious cause of peat decomposition is lowering of the water table. When the water table drops, anoxic pore water drains from the surface layer of the peat exposing it to air. Consequentially, the peat may rapidly oxidize (Minkkinen 2008; Couwenberg et al. 2010). Deforestation of tropical peat forest often entails building networks of canals used to float logs from the forest which drain the underlying peat, lowering the water table (Hooijer 2006).

Land use change impacts on the carbon cycle have been assessed through remote sensing (Miettinen et al. 2011), carbon stocks evaluation (Hergoualc'h et al. 2011) and measurement of gas exchange with the atmosphere (Jauhiainen et al. 2005; Jauhiainen et al. 2012; Hirano et al. 2009). Investigation of organic matter characteristics, including elemental and molecular analysis, is a useful tool to assess processes occurring in peat after exploitation or conversion, and to establish indicators of peat degradation (Kalbitz et al. 1999). Elemental composition and elemental ratios have been used for this purpose, especially $\mathrm{C} / \mathrm{N}$, in both temperate (Comont et al. 2006) and tropical (Anshari et al. 2010) peatlands, as well as molecular analysis of sugars (Comont et al. 2006) and FT-IR (Fourier transform infrared spectroscopy) analysis (Artz et al. 2008) in temperate peats. Dissolved organic carbon (DOC) is a key component of the carbon cycle in peatlands, which might contribute significantly to carbon budget assessment of these ecosystems (Hirano et al. 2009; Moore et al. 2011) both as a product and a substrate of microbial reactions (Porcal et al. 2009). Its composition reflects its origin (vegetation and soil leaching, microbial production) and reveals carbon cycling processes occurring in the peatland (Glatzel et al. 2003; Fellman et al. 2008). In temperate areas, DOC properties (UV absorbance, fluorescence properties) have been used to track processes occurring after drainage and conversion of a fen to agriculture (Kalbitz et al. 1999; Kalbitz et al. 2000). In tropical peatlands, investigations of land use change impact mainly focused on solid peat (Calvert et al. 1991; Anshari et al. 2010). DOC dynamic has been studied after its exportation to rivers in Indonesia (Baum et al. 2007, Rixen et al. 2008 Moore et al. 2011) and little information is available on DOM dynamic in pore water of pristine peatlands and land use change affects them.

The objective of the present work is to study solid and dissolved organic matter properties in a pristine and logged tropical peat forests of Brunei Darussalam to: (1) characterize organic matter properties in both solid and dissolved phases in a pristine tropical peat land; (2) determine how deforestation affects organic matter properties; (3) assess the implication of deforestation on the carbon cycle in tropical peatlands through organic matter properties.

\section{Materials and methods}

\section{Study site}

The study area is located in the Kuala Belait District in Brunei Darussalam on Borneo Island $\left(04^{\circ} \mathrm{N}, 114^{\circ} \mathrm{E}\right)$ where the climate is humid equatorial with $\sim 2.88 \pm$ $0.4 \mathrm{~m}$ of annual rainfall (data from the Brunei Meteorological Section from 1989 to 2005 in Seria). Two peat domes were investigated. One is covered by pristine primary forest (the Mendaram site); the other has recently been deforested (the Damit site). 
At the Mendaram site, two different vegetation zones are observed corresponding to zones two and three in the catenary sequence of peat swamp forest type described by Anderson (1983). In both zones, Shorea albida (large trees, up to $50 \mathrm{~m}$ high) and Pandanus sp. (up to $3 \mathrm{~m}$ high) are the main species. On the edge of the dome, Pandanus sp. are denser, whereas in the center of the dome, the opposite is observed.

The Damit dome is larger than the Mendaram (radius of $\sim 3.5$ in contrast to $2 \mathrm{~km}$ for the Mendaram). At this site, all the Shorea albida had been harvested with the exception of isolated very large trees and bad quality individuals. Logging began 30 years ago, so some areas have been recently logged, whereas others have experienced nearly 30 years of vegetation recovery. The early stages of recovery include herbaceous species and scrambling ferns, later replaced by Pandanus sp. and Nephrolepis biserrata, as well as shrubs and trees of Combretocarpus rotundatus. Compared with mono-dominant Shorea albida stands, the degraded site has a higher plant diversity, although Shorea albida is not expected to re-establish, due to the lack of seedlings (Kobayashi 1999).

\section{Sampling procedure and sample treatment}

Peat and pore water samples were collected from both domes along transects that extended from a river on the edge of the dome to a location near the center of each dome (Fig. 1). In the deforested site, the transect followed an existing trail. Two sampling locations (Ib, Ic) were added near the center of the dome, perpendicular to the main transect (the 'old' deforested area). These two sampling points were in areas that were logged much earlier than other points along the transect. Logging occurred along rail lines used to export timber and the rail had four positions during the 30 years of harvesting, from the east (where sampling points Ib and Ic are located) to the actual position. The current trail was started to be cut approximately 8 years ago. Logging activity occurred from the edge to the center of the dome, as the rail was extended towards the center of the dome. Thus, the sampling sites can be classified in three areas based on the time since logging: (1) The old deforested area (Ib, Ic) which was logged over 20 years ago, (2) The edge of the dome (III, IV, V) which was logged 10-15 years ago and, (3) The center of the dome (I, II) which was logged less than 3 years ago.

\section{Soil samples}

Surface peat was collected after litter removal to $15 \mathrm{~cm}$ depth and three replicates were sampled within a $10 \mathrm{~m}$-side square. Samples were placed in plastic bags, transported to the laboratory, and dried at $60{ }^{\circ} \mathrm{C}$. Then, roots were removed and the remaining dry material was ground in an agate mortar.

\section{Pore water samples}

Water samples were collected from three locations in the pristine site (III, IV, V) and five locations in the deforested site (I, Ic, II, IV and V), as well as from the Mendaram $(n=7)$ and Damit river $(n=2)$. At each location on the domes, water was collected from pools at the peat surface (the water table follows the land surface) and at depths of 10, 30, 60, and $180 \mathrm{~cm}$ using Inox pushpoint samplers (MHE products, USA) as piezometers. The piezometers were connected by tygon tubing (StGobain, France) to a hand pump and a flow-through cell containing probes (WTW probes, ConOX and Sentix 40) for in situ measurement of conductivity, dissolved oxygen (DO) and $\mathrm{pH}$. Pore water was sampled for laboratory analysis with a $50 \mathrm{ml}$ syringe filtered with surfactant-free cellulose acetate syringe filters $(0.2 \mu \mathrm{m})$. Samples were stored in glass bottles for TN and TOC analysis and in polypropylene bottles for subsequent analysis of major anions and cations analysis.

Chemical analysis

\section{Peat samples}

Loss on ignition (LOI) was determined from the weight of remaining mass after combusting a peat sample at $550{ }^{\circ} \mathrm{C}$. Soil $\mathrm{pH}$ was measured in $1 / 5(\mathrm{~m} / \mathrm{v})$ with $1 \mathrm{~g}$ of soil and $5 \mathrm{ml}$ of water. C, H, N and S analyses of soil samples were obtained from an Elementar Vario Micro Cube (ELEMENTAR Analysensysteme, Germany). Certified materials (NIST 1570a and 1632d) were included in the analytical loop to assess the accuracy of the methods. Certified values were achieved, with a minimal recovery of $90 \%$. The FT-IR spectra were acquired in transmittance mode using a spectrum 100 
Fig. 1 Map of the study area: Belait area, Brunei Darussalam. Location of the sampling points

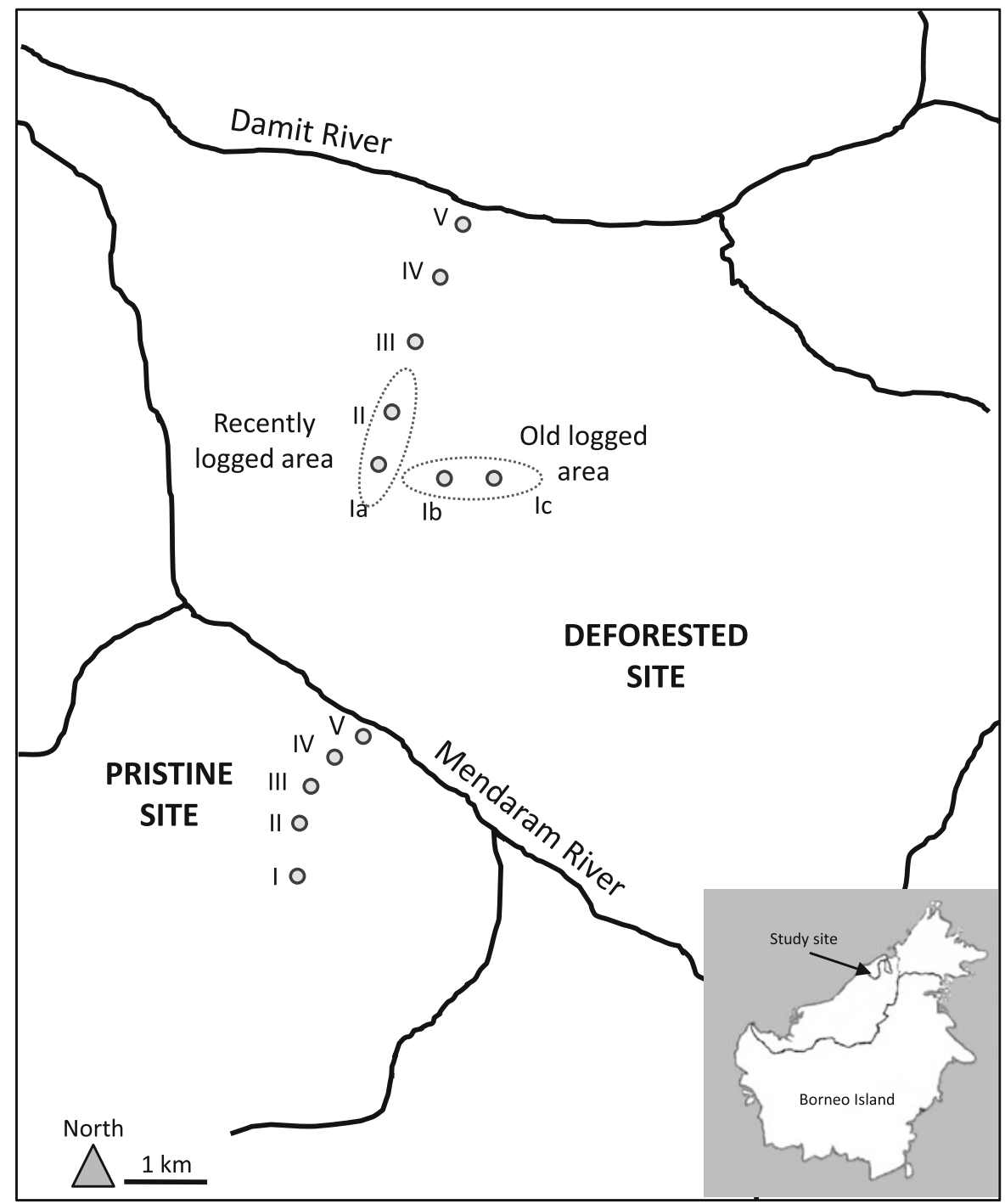

FT-IR spectrometer (Perkin-Elmer, USA). Potassium bromide pellets were obtained by pressing, under vacuum, a homogenized mixture of $400 \mathrm{mg}$ of infrared-grade $\mathrm{KBr}$ and $1 \mathrm{mg}$ of sample. Spectra were recorded in the range $4,000-400 \mathrm{~cm}^{-1}$ with $4 \mathrm{~cm}^{-1}$ resolution, and 4 scans were performed on each acquisition.

Ethanol extractable phenolic content was determined by a modification of the method of Singleton and Joseph Rossi (1965) using Folin-Ciocalteu reagents and gallic acid as standard. Peat extracts were obtained after orbital shaking of $0.5 \mathrm{~g}$ of peat in $5 \mathrm{ml}$ of ethanol $(80 \%)$ for $2 \mathrm{~h}$. The extracts $(0.3 \mathrm{ml})$ were diluted in Folin-Ciocalteu reagent $(2.25 \mathrm{ml})$. After reaction, sodium carbonate $(2.25 \mathrm{ml})$ was added to the green solution. The final reaction time before the solution turned blue was $90 \mathrm{~min}$. The ethanol extractable phenolic content was calculated based on the absorbance at $725 \mathrm{~nm}$, after calibration with gallic acid standards.

\section{Water samples}

Total nitrogen (TN), and non purgeable organic carbon (NPOC) were analyzed with a TOC-V CSH analyser (Shimadzu, Japan). TN was analysed on filtered but non acidified samples, and NPOC (after referred as DOC) was analyzed after $\mathrm{HCl}$ acidification to $\mathrm{pH}$ 2. Certified material (soft river water, Miramichi-02, Environment Canada) was included in the 
analytical loop to assess procedure accuracy. $\mathrm{NO}_{3}$ was analysed with an ion chromatograph (Methrom, The Netherlands). $\mathrm{NH}_{4}$ was analysed with a discrete analyser (WestCo SmartChem 200). The total phenolic content was determined using the same method described for peat samples.

The UV absorption spectra of pore water were measured with a spectrophotometer UV-1601 PC (Shimadzu, Japan) from 240 to $700 \mathrm{~nm}$ in a $1 \mathrm{~cm}$ quartz cell. The baseline was determined with ultra pure water. The specific UV absorbance at 280 (SUVA, $1 \mathrm{mg}^{-1} \mathrm{~m}^{-1}$ ) was calculated as follows:

SUVA $=\frac{A^{280}}{b[\mathrm{DOC}]}\left(1 \mathrm{mgC}^{-1} \mathrm{~m}^{-1}\right)$

where, $A^{280}$ is the sample absorbance at $280 \mathrm{~nm}$ (non dimensional), $b$ is the optical path length (m) and DOC is in $\mathrm{mg} \mathrm{l}^{-1}$. The absorbance at $280 \mathrm{~nm}$ was chosen instead of the usual $254 \mathrm{~nm}$ (Weishaar et al. 2003) since the high DOC concentration induced saturation of the spectrophotometer at $254 \mathrm{~nm}$. Fluorescence measurements were performed on pore water samples with a LS 45 Perkin Elmer (Norwalk, CT, USA) fluorescence spectrometer. Emission and excitation slits were set at a $5 \mathrm{~nm}$ bandwidth and a scan speed of $500 \mathrm{~nm} \mathrm{~min}{ }^{-1}$ was selected for both monochromators. Emissions spectra were recorded from 350 to $700 \mathrm{~nm}$ for 250,370 and $390 \mathrm{~nm}$ excitation, in order to determine fluorescence index. The intensity of the fluorescence spectra was normalized with the water Raman peak intensity at $350 \mathrm{~nm}$.

\section{Results}

Peat composition

\section{Bulk composition and chemical properties}

Peat samples collected from each location were characterized for organic matter content (loss on ignition) and elemental composition (Table 1). The ash content of the surface peat soils were below $3.2 \%$ in the pristine site, but a wider range of values was observed in the deforested site (from 0.4 to $5.7 \%$ ). At both sites, ash content increased from the center to the edge of the dome. The peat is acidic, showing nearly uniform $\mathrm{pH}$ values among peat samples, with a slight

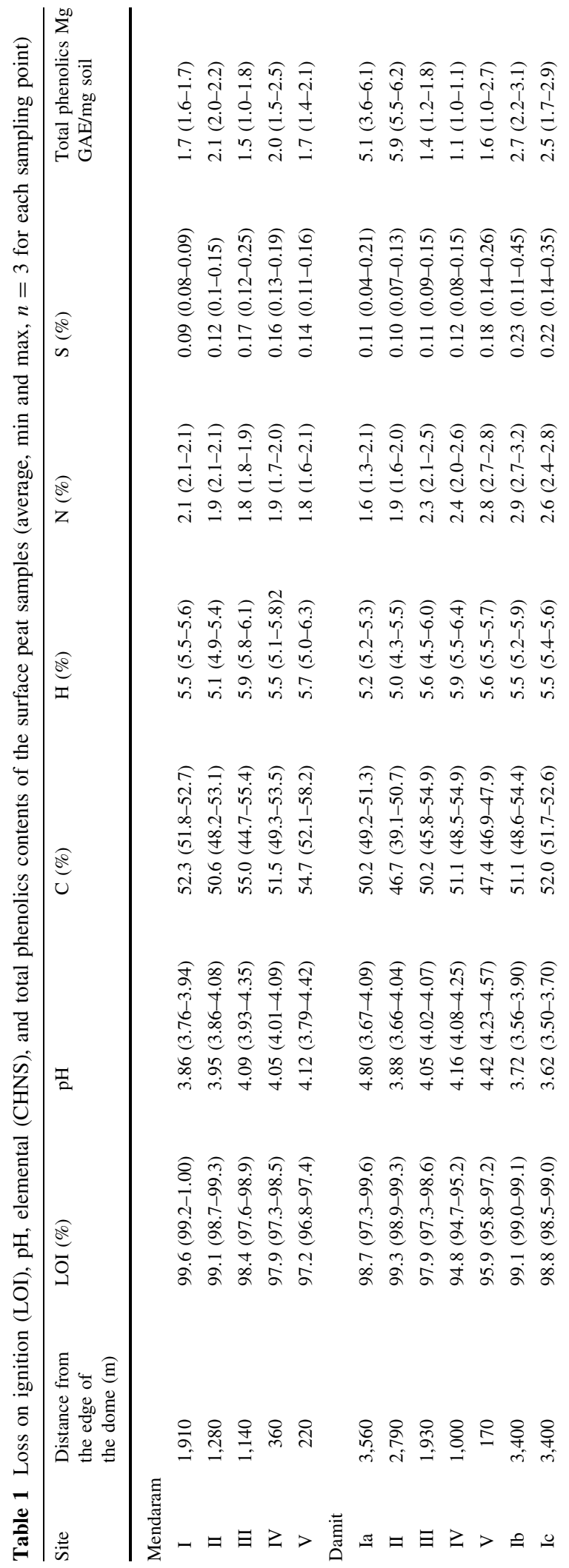




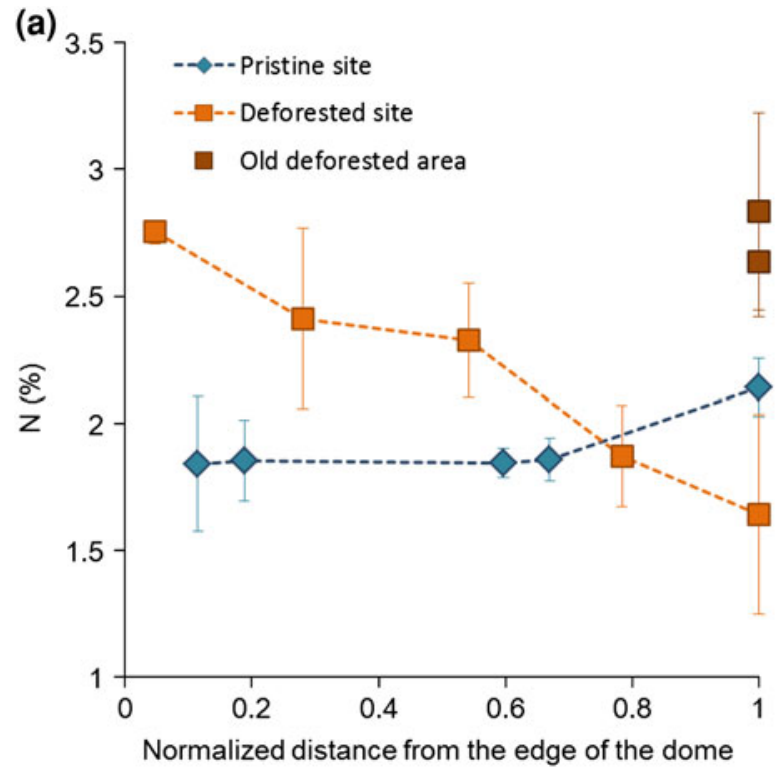

Fig. 2 a Nitrogen (\% of dry mass) content of surface soil of the two study area. b Ethanol extractable content of phenolics of the same samples. Since the two domes have different radius, distance from the edge of the dome has been normalized. Zero is the edge of the dome (the river) and one is the center of the

increase of $\mathrm{pH}$ (from 3.7 to 4.4 ) on the edge of the deforested dome compared to the center. The deforested site had a slightly lower carbon content (average value of $50 \%$ ) compared to the pristine site $(53 \%)$. Hydrogen content (mean value of $5.5 \%$ ) was homogenous along the two transects, with no significant difference between the two sites. Nitrogen concentrations (Fig. 2a) were stable along the sampling transect in the pristine site $(1.90 \pm 0.17 \%)$. In the deforested site, nitrogen concentration of the surface peat soil varied with sampling locations. Concentrations increased from the center $(1.42 \pm 0.44 \%)$ to the edge of the dome $(2.75 \pm 0.05 \%)$. Higher concentration were also observed in the radial transect, in the old deforested areas $(2.76 \pm 0.05 \%)$. Sulfur content slightly increased on the edge of each dome compared to the center (from 0.09 to $0.14 \%$ in the pristine site and from 0.11 to $0.18 \%$ in the deforested site). The highest values were measured in the 'old' deforested area $(0.22 \%)$.

\section{Organic matter properties}

Phenolics The ethanol extractable phenolics content in the surface soil showed contrasting results in the

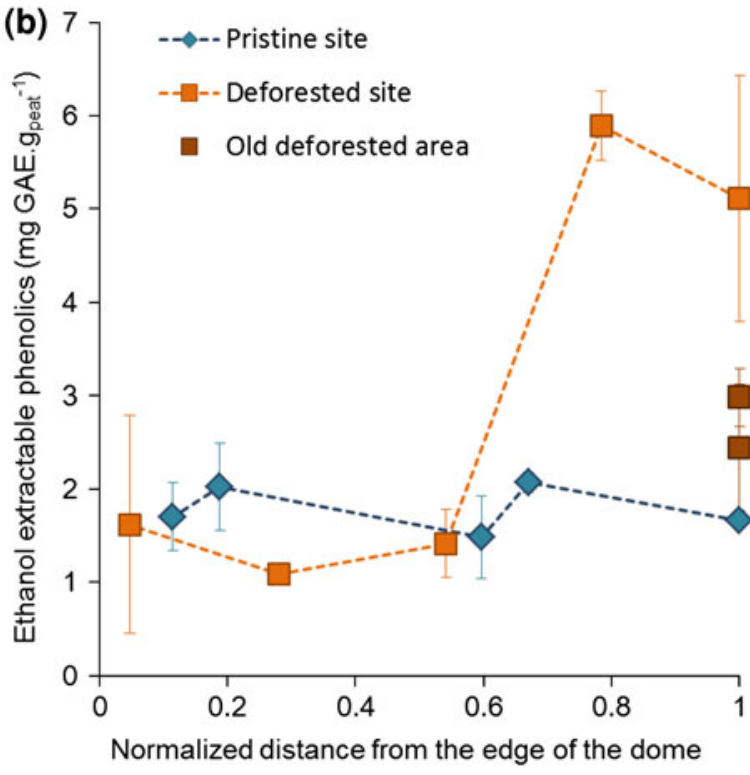

dome. In the deforested site, other sampling points (Ib and Ic) have been added in the center of the dome in an older deforested area. In each sampling site, three replicates were sampled in a $10 \mathrm{~m}^{2}$ and the three values are shown. The graph present the average and standard deviation of the three values

two sites (Fig. 2b). In the pristine site, the content of total phenolics was homogeneous within the dome and an average value of $1.7 \mathrm{mg} \mathrm{GAE} \mathrm{g}_{\text {soil }}^{-1}$ was measured. The phenolic content varied dramatically across samples from the deforested site. Sites III, IV and V presented an average value of $1.4 \mathrm{mg} \mathrm{GAE}_{\text {soil }}^{-1}$, whereas the two central sampling points (I,II) showed higher concentrations, with an average of $5.5 \mathrm{mg} \mathrm{GAE} \mathrm{g}_{\text {soil }}^{-1}$. The old forested site (Ia, Ib) presented intermediate values with an average of $2.9 \mathrm{mgGAE} \cdot \mathrm{g}_{\text {soil }}^{-1}$.

FT-IR spectra FT-IR spectroscopy is sensitive to specific organic functional groups and hence provides information about peat composition such as the presence of carbohydrates and proteinaceous compounds, as well as relative proportion of aromatic versus aliphatic compounds (Cocozza et al. 2003; Artz et al. 2008). The FT-IR spectra of our tropical peat samples exhibited typical peaks described for other peatlands, summarized by Artz et al. (2008). The surface soil spectra revealed a complex mixture of lignin, cellulose and hemicelluloses, typical of decomposition and transformation of vegetation material into peat. 
Fig. 3 FTIR absorbance spectra typical of the two studied sites. Spectra have been normalized

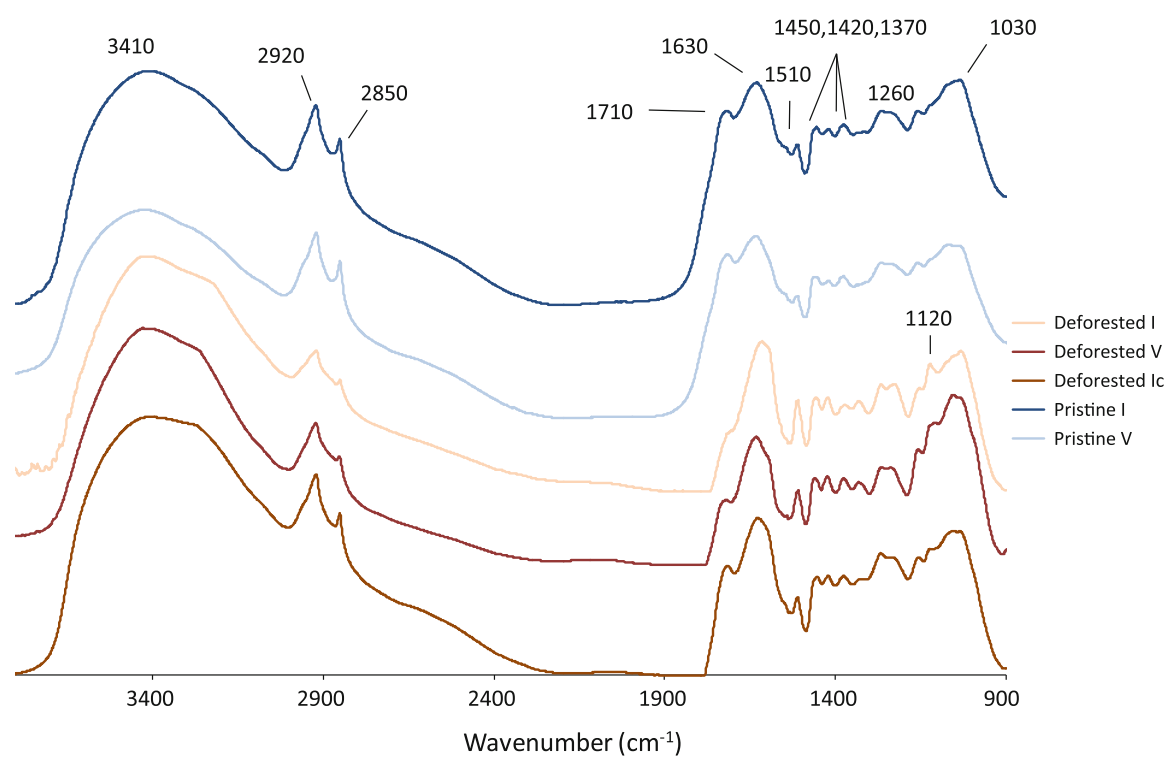

Some differences appeared between the pristine and the deforested site.

Spectra from all the samples have similar basic structures as demonstrated by the examples plotted in Fig. 3. A broad peak was observed at $3,410-3,420 \mathrm{~cm}^{-1}$, related to $\mathrm{O}-\mathrm{H}$ stretching of hydrogen in bonded $\mathrm{O}-\mathrm{H}$ groups, typical of polysaccharides. Two sharp peaks were observed at 2,850 and $2,920 \mathrm{~cm}^{-1}$, due to asymmetric stretching of aliphatic $\mathrm{C}-\mathrm{H}$, and attributed to fat, wax and lipids. Around $1,710 \mathrm{~cm}^{-1}$, a shoulder of varying intensity among samples was formed on a higher peak $\left(1,630 \mathrm{~cm}^{-1}\right)$. The shoulder is related to the $\mathrm{C}=\mathrm{O}$ stretch of $\mathrm{COOH}$ or COOR group and reveals the presence of carboxylic acids. The higher and wider absorption band around $1,630 \mathrm{~cm}^{-1}$ is ascribed to aromatic $\mathrm{C}=\mathrm{C}$ vibrations and $\mathrm{COO}^{-}$groups, indicating lignin and other aromatics. Another distinct peak appeared around $1,510 \mathrm{~cm}^{-1}$, also related to $\mathrm{C}=\mathrm{C}$ stretching, indicating lignin, other aromatics or $\mathrm{C}=\mathrm{N}$ bonds. This peak had a shoulder in some samples, around $1,550 \mathrm{~cm}^{-1}$, related to $\mathrm{N}-\mathrm{H}$ in plane. Three small peaks at $1,450,1,420$ and $1,370 \mathrm{~cm}^{-1}$, related to $\mathrm{C}-\mathrm{H}$ and $\mathrm{O}-\mathrm{H}$ deformations, were observed in both phenolic and aliphatic structures. A broader peak around $1,260 \mathrm{~cm}^{-1}$ was attributed to $\mathrm{C}-\mathrm{O}$ stretching of phenolic $\mathrm{OH}$ and indicative of lignin. A non attributed small peak was observed around $1,220 \mathrm{~cm}^{-1}$, as well as a broad peak around $1,030 \mathrm{~cm}^{-1}$, with two shoulders, one at $1,060 \mathrm{~cm}^{-1}$ and one at $1,120 \mathrm{~cm}^{-1}$ (depending on samples), related to $\mathrm{C}-\mathrm{O}$ stretching of polysaccharides. Small peaks were observed for lower wave numbers 790 , $770,690,530 \mathrm{~cm}^{-1}$. These peaks were not easily attributed to organic functions, since interference could occur with minerals in this area, even with low ash content.

Some characteristics of the spectra differed systematically between samples from the pristine site and the deforested sites. The 1,630 and $1,510 \mathrm{~cm}^{-1}$ peaks, revealing aromatic compounds $(\mathrm{C}=\mathrm{C}$ and $\mathrm{C}=\mathrm{N})$ were greater in the deforested site. In addition, the small peaks at 1,$450 ; 1,420 ; 1,370 \mathrm{~cm}^{-1}$ were clearer. Additional peaks at $1,120 \mathrm{~cm}^{-1}$ were observed in the deforested site. This indicates modification of peat organic matter composition from the pristine to the deforested site. The relative intensities of major FTIR peaks $\left(1,710 ; 1,630 ; 1,030 \mathrm{~cm}^{-1}\right)$ can be used as indicators of peat humification (Durig et al. 1988; Kalbitz et al. 1999). The 1,630/1,030 ratio reflecting the relative importance of phenolic compounds to polysaccharide compounds was close to one for all sampling sites, indicating no difference between the two peat domes. Values of the ratio of the 1,710/1,630 peaks were significantly lower $(p<0.001)$ in the deforested sites $(0.67 \pm 0.14)$ in comparison to those of the pristine sites $(0.83 \pm 0.06)$, indicating a higher proportion of aromatic structures relative to carboxyl compound and hence a greater humification of the organic matter in the deforested site (Kalbitz et al. 1999). 
Pore water composition

\section{Chemical composition}

Pore water composition appeared uniform over meterscale horizontal distances. Clustered measurements collected within several meters of each other on the same day had very similar chemical characteristics. Solute composition also appeared to be stable over the annual time scale. Repeated sampling in November 2010, February and July 2011 produced similar results. Concentration deviations among all samples collected at different times within a cluster never exceed $10 \%$, except for surface sample (15\%). The resulting standard deviations are listed in Table 2.

The electrical conductivity of the pore water was nearly uniform, both vertically and horizontally, and between the two domes with values ranging between 90 and $120 \mu \mathrm{S} \mathrm{cm}^{-1}$, except for a relatively high value of $533 \mu \mathrm{S} \mathrm{cm}^{-1}$ in the deep layer of the edge of the deforested site, likely due to the underneath clay influence. Pore water $\mathrm{pH}$ was low and in accordance with surface peat $\mathrm{pH}$ (Tables 1 and 2). In the pristine site, similar $\mathrm{pH}$ values (average value of 3.8 , ranging from 3.7 to 4.0 ) were measured in all pore-water samples. In the deforested site, slightly lower values were measured (average value of 3.7 , with values ranging from 3.6 to 5.3). High values (4.3 and 5.3) were measured at the edge of the dome, at $180 \mathrm{~cm}$ depth, on repetitive sampling occasions, reflecting the influence of the underlying clay layer, as also indicated by the higher conductivity values. The river water showed a slightly higher $\mathrm{pH}$, with values around 4 . Dissolved oxygen concentrations were very low. In the surface water, DO concentrations ranged from 0.6 to $1.7 \mathrm{mg} \mathrm{l}^{-1}$. DO concentrations decreased rapidly with depth, from 0.4 at $10 \mathrm{~cm}$ depth to less than $0.2 \mathrm{mg} \mathrm{l}^{-1}$ at $1.8 \mathrm{~m}$. This reflected a strong anoxic environment, similar in the two sites. River water was also anoxic. The samples were taken at about $10 \mathrm{~cm}$ below the surface level. Using the probe, DO concentrations were measured up to the surface layer and values never exceeded $0.8 \mathrm{mg} \mathrm{l}^{-1}$.

\section{Dissolved organic carbon}

Dissolved organic carbon concentrations were very high in the pore water (Table 2; Fig. 4a). In the pristine site, DOC concentrations in the pore water were nearly uniform, both vertically and horizontally, (with an average of $62.2 \pm 2.2 \mathrm{mg} \mathrm{l}^{-1}$, omitting an extreme value of $81.1 \mathrm{mg} \mathrm{l}^{-1}$ measured in the surface water). Significantly $(p<0.001)$ higher DOC concentrations were observed in the deforested site (79.9 \pm $5.5 \mathrm{mg} \mathrm{l}^{-1}$, Fig. 6a) except on the edge of the dome (sampling point $\mathrm{V}$ ) where DOC concentrations were much lower in the surface layers $\left(53.8 \mathrm{mg} \mathrm{l}^{-1}\right)$ than in the deep layers $\left(68.1 \pm 11.9 \mathrm{mg} \mathrm{l}^{-1}\right.$ measured at $180 \mathrm{~cm}$ depth) (Fig. 4a). The DOC concentrations of river water were lower than the pore water (Table 2: 28.1-38.5 $\mathrm{mg} \mathrm{l}^{-1}$ ) and higher than the concentrations measured by (Baum et al. 2007) in the Siak river in Sumatra, but in the low range of the concentration measured by (Moore et al. 2011) in the river Sebangau in South Kalimantan.

The ethanol extractable phenolic concentration in the pore water differed between the two sites (Fig. 4b). In the pristine site, no differences between sampling sites were observed. An average value of $19.3 \mathrm{mg} \mathrm{GAE} 1^{-1}$ was measured, with a slight decrease of the concentration in the surface layers. In the deforested site, phenolic content of the pore water varied across locations. An increase of the total phenolic concentration was observed from the edge (V, IV) to the centre of the dome (Ia and Ib). The concentrations sharply decreased in the upper layers, especially on the edge and in the old deforested area indicating a higher decomposition of these compounds in the surface layers. The phenolic concentration in the $10 \mathrm{~cm}$ deep pore water reflected the pattern already observed in the solid peat, with a higher concentration in the recently logged area (I) compared to the edge (V, IV) and the old deforested areas (Ic).

Dissolved organic nitrogen Dissolved total nitrogen values were significantly lower in the pristine site $\left(1.09 \pm 0.09 \mathrm{mg}^{-1}\right.$, ranging from 0.91 to $\left.1.26 \mathrm{mg} \mathrm{l}^{-1}\right)$ compared to the deforested site $\left(1.65 \pm 0.35 \mathrm{mg} \mathrm{l}^{-1}\right.$, ranging from 1.29 to $2.75 \mathrm{mg} \mathrm{l}^{-1}$ ). Dissolved organic nitrogen values were calculated by subtracting $\mathrm{NO}_{3}$ and $\mathrm{NH}_{4}$ values from $\mathrm{TN}$. As a whole, $\mathrm{NO}_{3}$ values were very low (average value of $0.02 \pm 0.006 \mathrm{mg} \mathrm{l}^{-1}$ in the two sites, data not shown) and often close to the detection limit. $\mathrm{NH}_{4}$ values were higher (average value $=0.10 \pm$ $0.07 \mathrm{mg} \mathrm{l}^{-1}$, data not shown), with higher concentrations in the deep layer compared to the surface. No differences were observed between sampling sites and between the two studied domes for inorganic nitrogen concentrations. Nitrogen was mostly ( $>90 \%$ ) present as dissolved organic nitrogen (DON), so DON trends were 


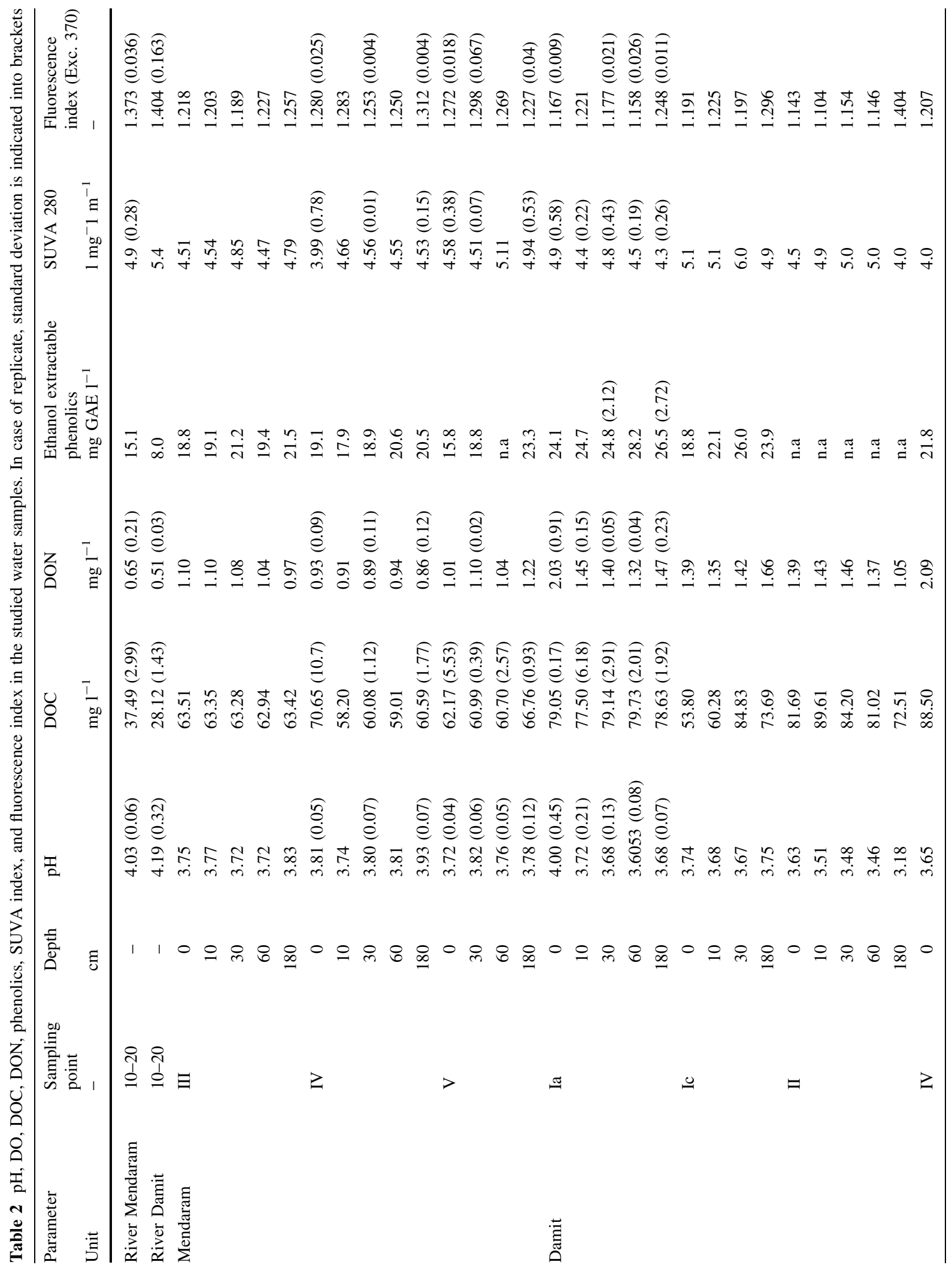




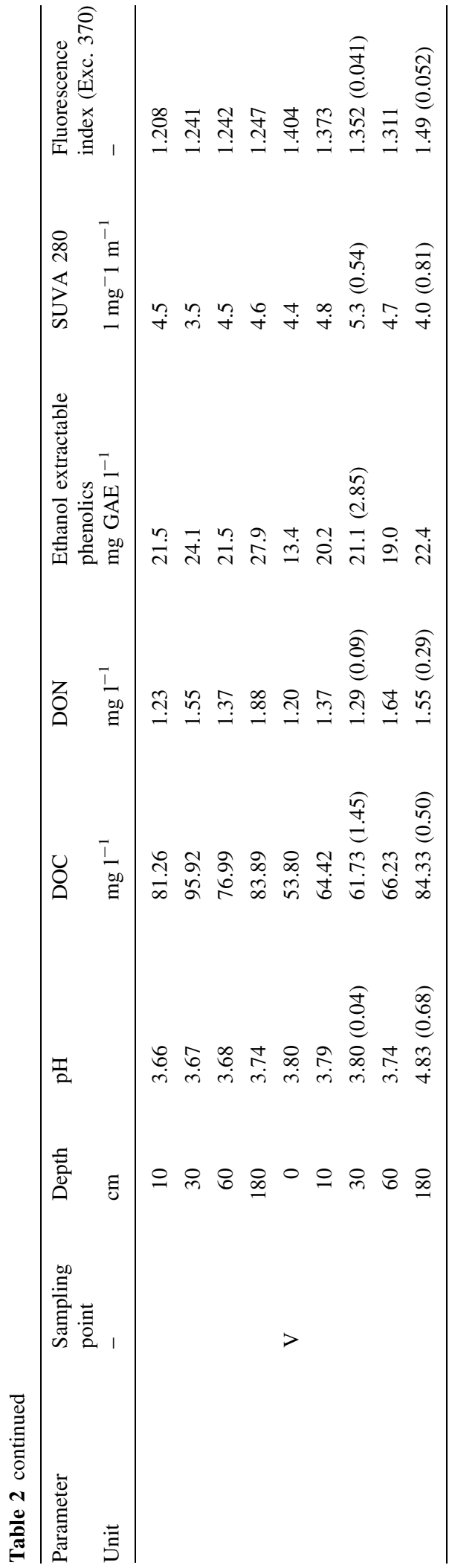

similar to total nitrogen trends. DON values (Fig. 4c) in the pore water were significantly $(p<0.001)$ lower in the pristine site $\left(0.99 \pm 0.08 \mathrm{mg} \mathrm{l}^{-1}\right.$, ranging from 0.89 to $1.14 \mathrm{mg} \mathrm{l}^{-1}$ ) compared to the deforested site $\left(1.56 \pm 0.35 \mathrm{mg} \mathrm{l}^{-1}\right.$, ranging from 1.02 to 2.73 $\mathrm{mg}^{-1}$ ). These values are low compared to the values reported in temperate peat (Kalbitz et al. 2000). As a whole, significantly $(p<0.001)$ lower values of the DOC/DON ratio were observed in the deforested site compared to the pristine site, indicating that the dissolved organic matter (DOM) is enriched in nitrogen in the deforested site compared to the pristine site.

\section{Optic properties of DOC}

Absorbance The optical properties of DOC were used to characterise dissolved organic molecules. Ultraviolet absorbance from 200 to $700 \mathrm{~nm}$ showed typical features of increasing absorbance at lower wavelengths for both pore water and river water. For samples from the pristine site, specific absorbance at $280 \mathrm{~nm}$ was important, with an average value of $4.5 \pm 0.31 \mathrm{mgC}^{-1} \mathrm{~m}^{-1}$, was nearly constant with depth. In the deforested site, values differed more across samples, with SUVA ranging from 3.5 to $61 \mathrm{mgC}^{-1} \mathrm{~m}^{-1}$. This wavelength is an indication of DOC aromaticity because $\pi-\pi *$ electron transitions occur in this region of the UV range, from -270 to $280 \mathrm{~nm}$ for phenolic substances, aniline derivatives, benzoic acids, polyenes, and polycyclic (Chin et al. 1994). Then, these elevated SUVA values are likely to be related to high aromaticity content of the pore water DOM (Chin et al. 1994; Weishaar et al. 2003). Relative to other values from the literature, these values are high, corresponding to the highest values reported by Weishaar et al. (2003) for water collected in different ecosystems, and higher than the values reported by Moore and Clarkson (2007) for New Zealand peat pore water $\left(1.9-3.51 \mathrm{mgC}^{-1} \mathrm{~m}^{-1}\right)$ and by Jones et al. (2009) for UK bogs. The SUVA values for all vertical profiles of DOC showed similar patterns, with increasing values from the surface to $30 \mathrm{~cm}$ depth then a decrease to $180 \mathrm{~cm}$, indicating a potential accumulation of aromatic molecules around $30 \mathrm{~cm}$ depth. No differences in SUVA indices were observed in the river water compared to the pore water.

Fluorescence The emission excitation matrix (EEM) spectra of pore water had two distinct 


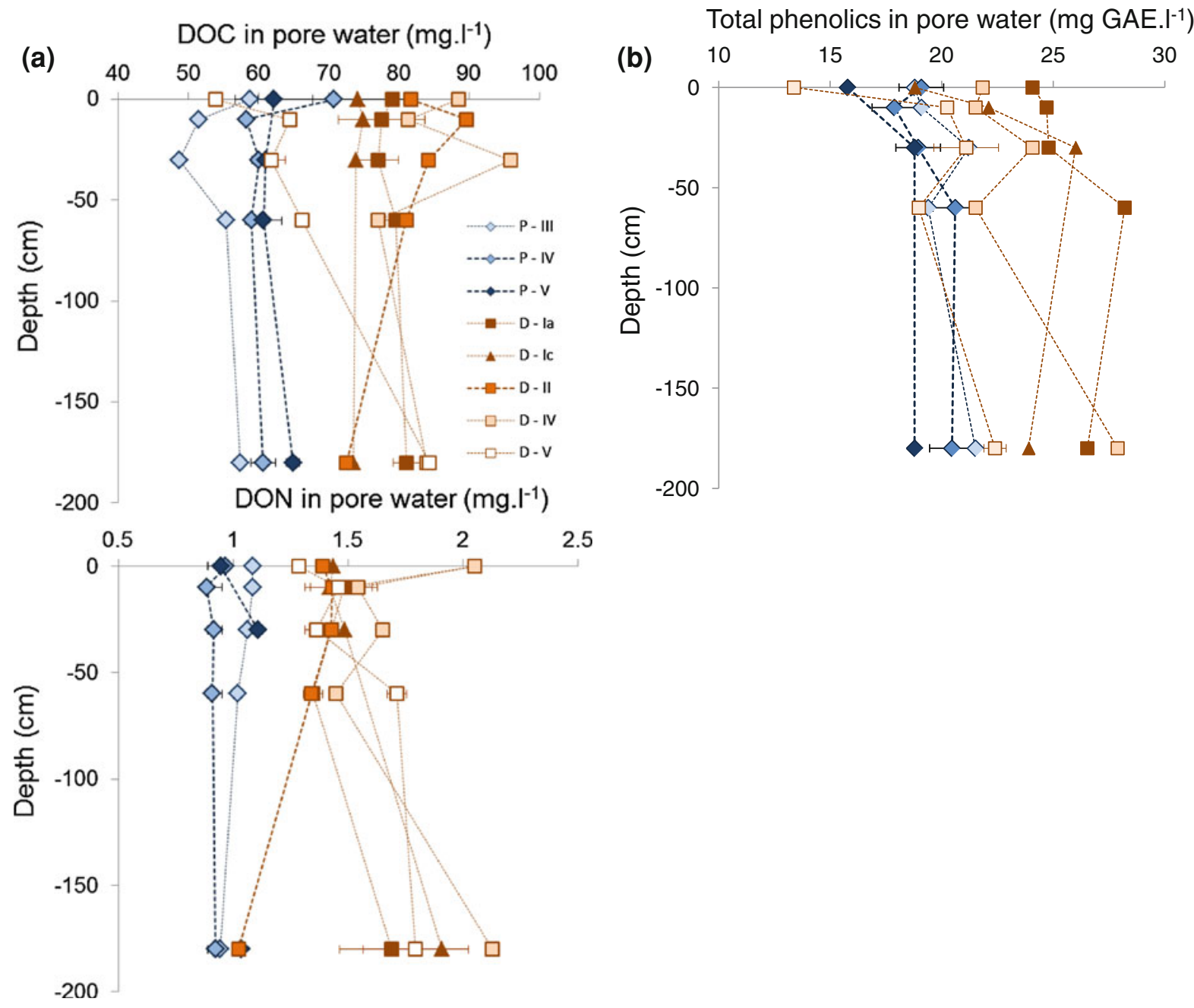

Fig. 4 a DOC concentration in the pore water profiles. b Total phenolics concentrations in the pore water. c Dissolved Organic Nitrogen concentrations in the pore water. When available, the error bars indicate the standard deviation of repeated sampling

fluorophores, $\alpha$ and $\beta$, identified by the emission excitation wavelength pairs $($ EEWP) $<390 \mathrm{ex} / 470$ 490em and 260ex/450em, respectively (Example given in Fig. 5a). The main fluorophore $(\alpha)$ is typical of humic molecules, The $\beta$ fluorophore, with a slightly shifted emission wavelength (from 480 to 450) for lower excitation (260) is attributed to UV humic like or fulvic acids, characterized by similar properties compared to the first fluorophores, but less aromaticity and fewer functional groups (Chen et al. 2003; Maie et al. 2006; Zaccone et al. 2009). In order to identify major sources and transformation mechanisms of the DOM in the pore water and river water, fluorescence index were calculated (Fig. 5b). Fluorescence Index (FI) was defined (McKnight et al. 2001) as the ratio of the emission intensities at 450 and $500 \mathrm{~nm}$ for an excitation wavelength of $370 \mathrm{~nm}$. Higher values indicate a predominant microbial origin of DOM, whereas lower values reflect more aromatic molecules, originating from soil and plants (McKnight et al. 2001). It was then modified by Maie et al. (2006) as the ratio of the emission intensities at 470 and 520, for the same excitation wavelength $(370 \mathrm{~nm})$.

Lower FI values were measured in the pore water compared to the river water $(1.4 \pm 0.04)$, indicating a higher microbial activity in the river. In the pristine site, FI range from 1.19 to 1.41 , with an average of $1.27 \pm 0.05$. The different sampling sites showed slight differences in the upper layers, where lower FI were measured in sampling point III (inner dome, from 1.19 to 1.23 ) 
(a)

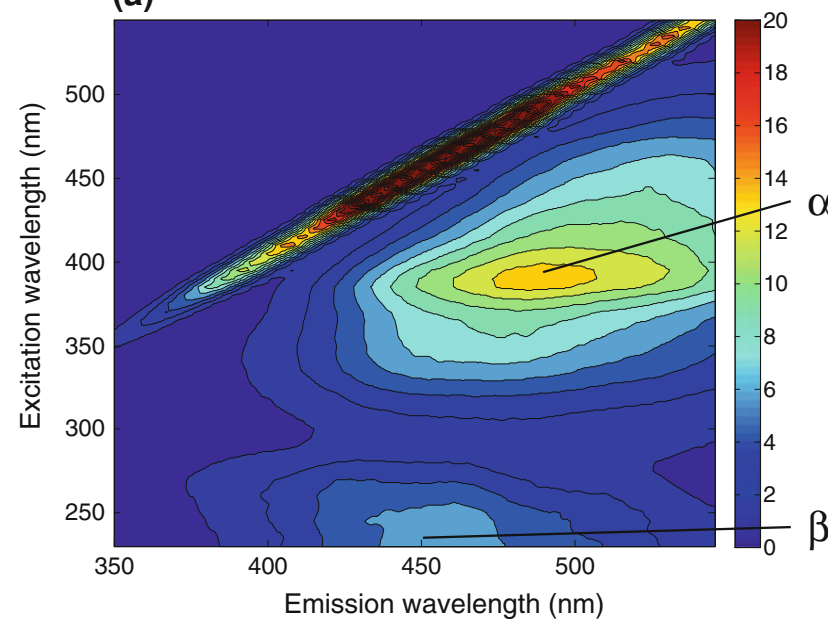

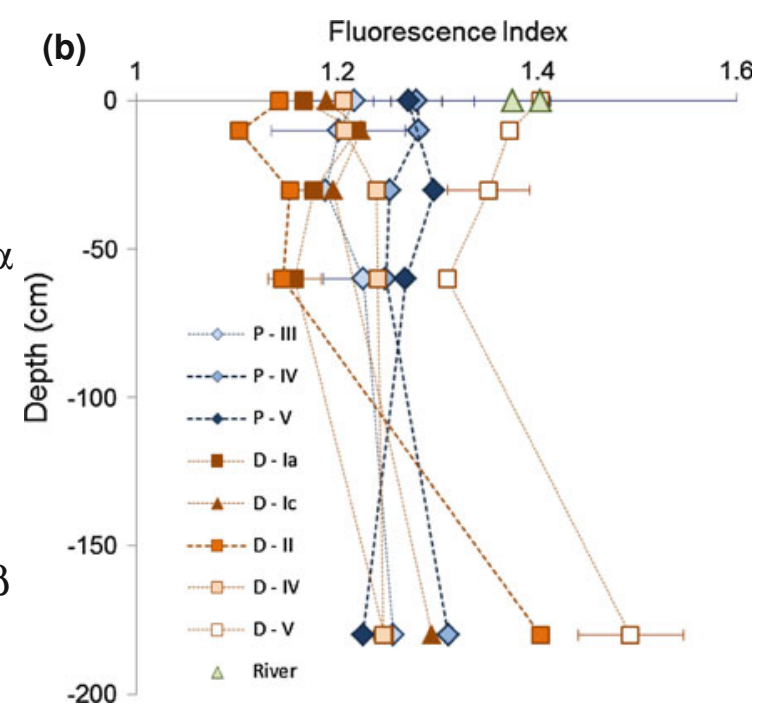

Fig. 5 a Example of excitation emission matrix of pore water in the deforested site. b Evolution of fluorescence index with depth in pore water in the different sampling locations. When available, the error bars indicate the standard deviation of repeated sampling

compared to sampling point IV and V (edge of the dome, $1.25-1.30)$. In the deforested site, a wider range of values was measured (ranging from 1.10 to 1.55 ). Low values were noticed in the dome (1.10 to 1.22 for sampling points Ia, Ic and III) and increased on the edge of the dome (1.37 to 1.55 for sampling point V). These values are in the range of reported values in the Florida Everglades (1.28-1.48) by Yamashita et al. (2010). The differences observed between sampling sites in the deforested site are sufficient to consider different that DOM originates from different sources or has undergone different level of processing in the different sampling points. In the deforested site, with the exception of sampling point $\mathrm{V}$ (edge of the dome), lower FI values were measured, compared to the pristine site, indicating a higher proportion of terrestrially derived DOM. On the edge of the deforested dome, significantly higher $(p<0.001)$ values of fluorescence index were measured, indicating a higher proportion of microbial derived DOM (McKnight et al. 2001; Maie et al. 2006; Yamashita et al. 2010).

\section{Discussion and conclusions}

Organic matter characteristics in tropical peat forest

The main organic functional groups (carbohydrates, phenolics, carboxylates) identified by FTIR analysis were similar to with those found in temperate peat originating from sphagnum (Chapman et al. 2001; Cocozza et al. 2003; Artz et al. 2008). These functional groups are consistent with a composition dominated by lignin, lignocellulose and cellulose, as the result of various decomposition stages of plant material. The overall composition of peat from both domes was similar to that reported for other tropical peat lands (Durig et al. 1988; Calvert et al. 1991). FTIR analysis showed a particularly strong predominance of lignin associated peaks in relation to the wood origin of the peat: forest of Shorea albida trees growing on the pristine site, and previously growing on the deforested site (Durig et al. 1988; Williams et al. 1998).

Very high concentrations of DOC were measured in the pore water and the river water draining the domes. DOC concentrations in pore water ranged between 55 and $95 \mathrm{mg}^{-1}$. The values reported in the pristine site were lower than the values reported by Yule and Gomez (2009) for a disturbed peatland in peninsular Malaysia (74-84 $\mathrm{mg} \mathrm{l}^{-1}$ ), and slightly lower than the ones reported by Miyamoto et al. (2009) for a peatland converted to sago plantation and a secondary forest in Indonesia (70-104 $\mathrm{mg}^{-1}$ ). The fluorescence analysis of DOM revealed the predominance of humic acids, directly originating from vegetation and peat leaching and peat decomposition. The SUVA values being higher than the ones classically reported for temperate 

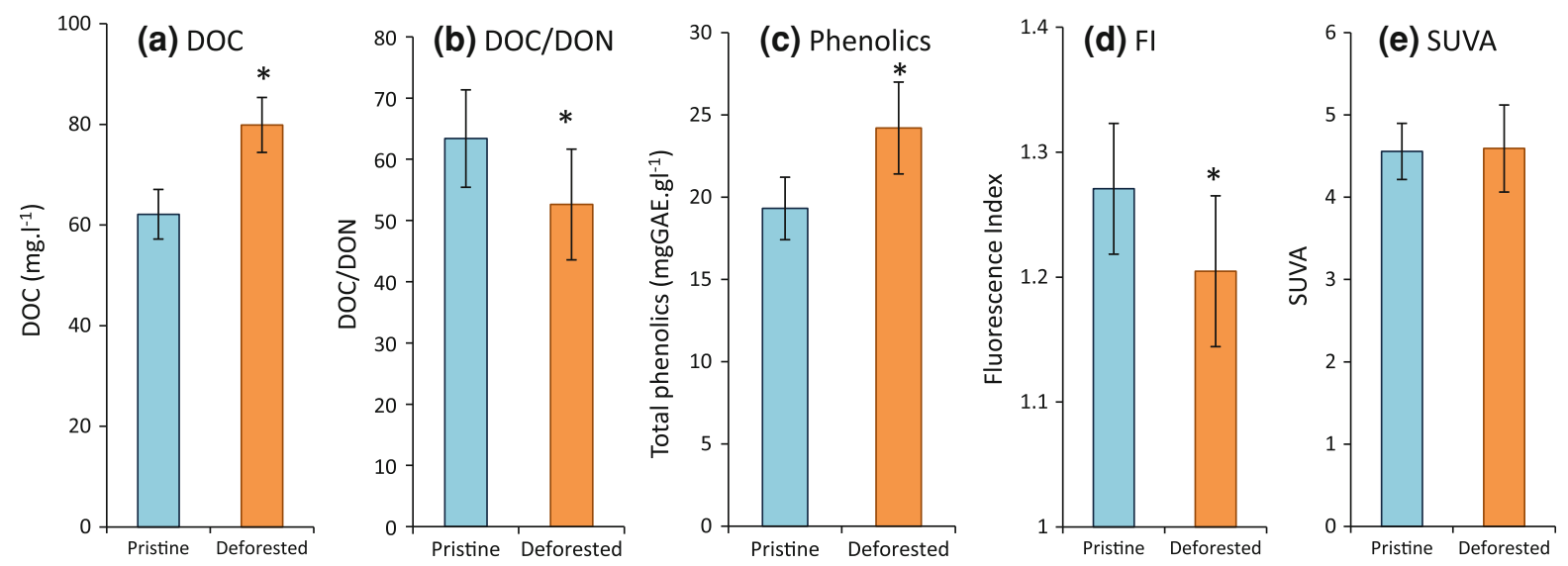

Fig. 6 Comparison of dissolved organic matter (DOM) properties between the pristine and the deforested site. a DOC concentration. b DOC/DON. c Total phenolic concentration. d Fluorescence index of the pore water. e SUVA index. The average of all profiles and all depths are presented. $n=29$ for

peatland (Moore and Clarkson 2007), the DOM in river and pore water is expected to be highly aromatic.

Impact of logging: comparison of dissolved organic matter (DOM) between the logged and pristine domes

Our study is the first to compare DOM properties in pore water of a logged peat dome to an adjacent undisturbed dome. Although some contrasts are evident in the surface peat, DOM shows the most pronounced differences between the two domes (Fig. 6). To calculate the average values (Fig. 6), we disregarded the data from the very edge of the pristine site (location V) because chemical characteristics of these samples (fluorescence, phenolics and DOC concentration) all indicated that an input of river water, mixing peat pore water and river water. This mixture does not appear to represent pore water that has evolved solely within the peat dome. Pore water samples from the edge of the pristine site do not appear to have been mixed with river water, suggesting perhaps that enhanced peat decomposition followed by subsidence favored flooding on the edge of the deforested site, explaining that the pore water composition on the edge of the deforested dome is influenced by the river.

Average DOC concentration $\left(79.9 \pm 5.5 \mathrm{mg} \mathrm{l}^{-1}\right)$ in the pore water of the deforested dome was $30 \%$ greater than the undisturbed dome $\left(62.2 \pm 2.2 \mathrm{mg} \mathrm{l}^{-1}\right)$. Clear

the pristine site, $n=30$ for the deforested site. In the deforested site, the edge profile has been removed, due to the influence of river water on the chemistry. The significant differences $(*)$ are tested using a one way $t$ test $(p<0.0001)$

cutting of forest has been shown to induce a short term (3-5 years) flush of DOC in forest soils (Yanai et al. 2003; Kreutzweiser et al. 2008). In this study, the higher DOC concentrations are unlikely to reflect this DOC flush because logging proceeded over 30 years across the dome and the DOC concentrations were nearly uniform across the dome. The increase in DOC concentrations indicates increased peat decomposition in the deforested site and following accumulation of DOM in the pore water. DOM properties also differed between the two sites: the nitrogen to carbon ratio, phenolic content and fluorescence index of the DOM all had robust statistical differences between the two domes (Fig. 6). The higher nitrogen content of DOC in the deforested site (as indicated by the lower DOC/DON ratio in Fig. 6b) was consistent with the overall increase of nitrogen content of the peat in the deforested site (Fig. 2a). The higher phenolic concentrations measured in the pore water in the deforested site (Figs. 4b, 6c) might originate from extra input of fresh litter from the discarded branches and leaves left on the surface after logging (Williams et al. 1998), since vegetation is rich in phenolic compounds (Appel 1993). The phenolic concentration in the pore water presented similar profiles in the deforested site, with a decrease of concentration in the upper layers and increase in the middle layer of the peat $(30 \mathrm{~cm})$. This pattern might indicate preferential decomposition of these compounds in the surface layers, in relation with intermittent aeration of the surface layers (Worrall and Burt 2005). This could indicate that 
oxygenation of the surface layers of the deforested peat has occurred, even if no differences were noticed in the dissolved oxygen concentrations in the pore water between the two sites.

The SUVA index does not indicate changes between the two domes. In contrast, the fluorescence properties of DOM showed a wider range of values in the deforested site compared to the pristine site. Lower values of FI were observed in the center of the dome (Fig. 6d), suggesting a more important contribution of molecules originating from peat and litter, (McKnight et al. 2001) in relation to enhanced peat decomposition. This extra input of DOM to pore water do no undergo a high cycling and tends to accumulate, leading to a significant increase of DOC concentrations in the pore water in the deforested site. Higher values of FI were observed on the edge of the dome, closer to the river, indicating a higher microbial activity in this area, and subsequent reduction of DOC concentrations.

Impact of logging activity on peat composition

Analysis of the solid peat samples also indicated higher peat decomposition in the deforested site. The differences observed between sampling sites in the deforested site may reflect different logging histories. FTIR spectra from the deforested site differed from those from the pristine site for the relative importance of the different peaks, especially the lignin ones. The $1,710 / 1,630$ peaks ratio was significantly lower in the deforested site. A lower value of this ratio has been identified as an indicator of peat decomposition (Kalbitz et al. 1999). The nitrogen and sulfur content of solid organic matter also indicated enhanced peat decomposition in the deforested site. The higher sulfur contents of the surface peat on the edge and in the old deforested area may reflect the relative enrichment in sulfur after peat decomposition. The nitrogen content also differed in peat from the deforested site, and varied between sampling sites. Increased nitrogen content was observed in the old logged areas and on the edge of the dome (Fig. 2a). Higher nitrogen content has been used as an indicator of peat oxidative decomposition and degradation (Malmer 1984; Anshari et al. 2010). During peat evolution, carbon is preferentially lost from through aerobic decomposition of easily disintegrating carbohydrates (Clymo 1984). This results in an enrichment of nitrogen in the peat (Kuhry and Vitt 1996). In the two domes, DOC/DON values in the pore water (ranging from 28 to 89 ) were higher than $\mathrm{C} / \mathrm{N}$ values in the solid peat (17-42) in the two sites, indicating a relatively lower release of nitrogen-rich molecules in the pore water. In the recently logged area, $\mathrm{N}$ content of solid organic matter was not modified compared to the pristine site (Fig. 2a). In these areas, higher phenolic content was measured in the peat (Fig. 2b). Phenolic compounds, present in numerous plant species (Appel 1993) could have been added to the peat surface as a result of decomposition of logging leftover. These compounds are known to inhibit peat decomposition (Freeman et al. 2004). This could explain the fact that in the recently logged areas, no significant modification of the nitrogen content of the soil was observed. We hypothesize that logging exploitation of the peat forest has induced higher peat decomposition. Although, this effect could be time dependent. Just after logging, the release of phenolic compounds could have an inhibitory effect, disappearing after decomposition and leaching of the phenolic compounds.

Implications for carbon fluxes

Our deforested site was not drained, and hence it differs from other deforested tropical peat domes that have been described in the literature which were drained (Hooijer 2006; Hirano et al. 2007). Logging in tropical peat forests is often accompanied by drying, oxidation, and loss of upper layers of peat because of the lowering of the water table (Couwenberg et al. 2010; Page et al. 2011b). Canals that are excavated to transport logs from the forest also drain water from the peat domes. The subsequent lowering of the water table exposes peat to oxygen and increases $\mathrm{CO}_{2}$ emissions. Although, the effect of water table lowering on $\mathrm{CO}_{2}$ emissions might be complicated by other factors, including vegetation regrowth, litter quality, temperature and acidity (Laiho 2006).

At our site, logs were exported on temporary rail lines constructed on the peat surface, rather than by canals. Thus, our results suggest that deforestation may drive oxidation of peat even with no engineered lowering of the water table. Logging activity is known to cause a short term nutrient flush due to left over decomposition (Kreutzweiser et al. 2008). No modification of the major cation and anion concentrations of the pore water was observed between the two 
domes. Although, this flush could have occurred just after logging and therefore stimulated microbial activity. The other parameters driving peat oxidation (especially temperature, and moisture (Jennings et al. 2009; Ise and Moorcroft, 2006)) might have been deeply modified by deforestation, by allowing increased solar radiation and therefore heating of the surface of the peat (Jauhiainen et al. 2012), or by physical modifications of the surface that increase runoff, potentially drying the peat. Here, the reduction of phenolic concentration and SUVA index in the upper layer of the deforested site may indicate that aeration of the surface layers of the deforested peat has occurred.

Based on the DOC concentration in pore water, the carbon export to the river can be estimated. A rough estimation of runoff can be made using the average precipitation rate measured by the Brunei Meteorological Section from 1989 to 2005 $\left(2.88 \pm 0.4 \mathrm{~m} \mathrm{year}^{-1}\right)$ and the value of total evaporative loss (evapotranspiration + interception) evaluated by Hooijer (2005) of $1,500 \mathrm{~m} \mathrm{year}^{-1}$ for the Jerumong catchment in Sarawak. An average DOC export to rivers of $81 \pm 28 \mathrm{gC} \mathrm{m}^{-2}$ year $^{-1}$ in the pristine site can be estimated. This is consistent with the estimate of Moore et al. (2011) of a flux of $88 \mathrm{gC} \mathrm{m}^{-2}$ year $^{-1}$ released from the Sebangau catchment in Kalimantan. The carbon export in the deforested is difficult to assess, since evaporative fluxes might have been modified in the deforested site. Since deforestation is more likely to have decreased evapotranspiration and interception (Asdak et al. 1998), run off fluxes might have increased. A conservative estimate of the flux can be made considering no change in the runoff. The average flux is then estimated to $104 \pm 39 \mathrm{gC} \mathrm{m}^{-2}$ year $^{-1}$ representing an increase of $23 \mathrm{gC} \mathrm{m}^{-2}$ year $^{-1}(23 \%)$ following deforestation. These fluxes represents a significant proportion (from 23 to $29 \%$ ) of the NEP (net ecosystem production) evaluated by Hirano et al. (2009) for a drained forest in Kalimantan ( $372 \mathrm{gC} \mathrm{m}^{-2}$ year $\left.^{-1}\right)$, based on the difference of ecosystem productivity and respiration. The fluvial export of carbon from tropical peatlands appears to be significant for the overall carbon budget assessment. This flux could be increased by logging activity, since in the deforested site, an increase of DOC concentration in the pore water is observed, in relation to enhanced peat decomposition. The microbial activity and the very low dissolved oxygen concentrations on the edge of the deforested dome and in the river, show that some of the DOM must be consumed in the river, providing a flux of $\mathrm{CO}_{2}$ to the atmosphere.

Acknowledgments This project is funded by the Singapore National Research Foundation (NRF) through the SingaporeMIT Alliance for Research and Technology (SMART) Center for Environmental Sensing and Monitoring (CENSAM). Laure Gandois benefited from a SMART post doctoral fellowship. The authors warmly thank Richard Corlett for facilitating access to analytical facilities at NUS, Amy Chua, Kai Fu Ming, Shaliha Suut and Jang Ak.Eri from the Forestry Department in Brunei for their great help during field work, as well as Scott Fendorf, Guangchao Li and Doug Turner of the EM-I analytical center at Stanford University, and the staff of the Department of Chemistry at NUS for great help in samples analysis.

\section{References}

Anderson JAR (1983) The tropical peat swamps of Western Malaysia. Ecosyst World 4b:181-199

Anshari GZ, Afifudin M, Nuriman M, Gusmayanti E, Arianie L, Susana R, Nusantara RW, Sugardjito J, Rafiastanto A (2010) Drainage and land use impacts on changes in selected peat properties and peat degradation in West Kalimantan Province, Indonesia. Biogeosciences 7(11):34033419

Appel MH (1993) Phenolics in ecological interactions: the importance of oxidation. J Chem Ecol 19(7):1521-1552

Artz RRE, Chapman SJ, Robertson AHJ, Potts JM, LaggounDéfarge F, Gogo S, Comont L, Disnar J-R, Francez A-J (2008) FTIR spectroscopy can be used as a screening tool for organic matter quality in regenerating cutover peatlands. Soil Biol Biochem 40(2):515-527

Asdak C, Jarvis PG, van Gardingen P, Fraser A (1998) Rainfall interception loss in unlogged and logged forest areas of Central Kalimantan, Indonesia. J Hydrol 206(3-4): 237-244

Bala G, Caldeira K, Wickett M, Phillips TJ, Lobell DB, Delire C, Mirin A (2007) Combined climate and carbon-cycle effects of large-scale deforestation. Proc Natl Acad Sci USA 104(16):6550-6555

Baum A, Rixen T, Samiaji J (2007) Relevance of peat draining rivers in Central Sumatra for the riverine input of dissolved organic carbon into the ocean. Estuar Coast Shelf Sci 73(3-4):563-570

Calvert GD, Durig JR, Esterle JS (1991) Controls on the chemical variability of peat types in a domed peat deposit, Baram River Area, Sarawak, Malaysia. Int J Coal Geol 17(2):171-188

Chen W, Westerhoff P, Leenheer JA, Booksh K (2003) Fluorescence excitation-emission matrix regional integration to quantify spectra for dissolved organic matter. Environ Sci Technol 37(24):5701-5710

Chin YP, Aiken G, Oloughlin E (1994) Molecular-weight, polydispersity and spectroscopic properties of aquatic humic substances. Environ Sci Technol 28(11):1853-1858 
Clymo RS (1984) The limits to peat bog growth. Philos Trans R Soc Lond Ser 303(1117):605-654

Cocozza C, D’Orazio V, Miano TM, Shotyk W (2003) Characterization of solid and aqueous phases of a peat bog profile using molecular fluorescence spectroscopy, ESR and FT-IR, and comparison with physical properties. Org Geochem 34(1):49-60

Comont L, Laggoun-Défarge F, Disnar J-R (2006) Evolution of organic matter indicators in response to major environmental changes: the case of a formerly cut-over peat bog (Le Russey, Jura Mountains, France). Org Geochem 37(12):1736-1751

Couwenberg J, Dommain R, Joosten H (2010) Greenhouse gas fluxes from tropical peatlands in south-east Asia. Glob Change Biol 16(6):1715-1732

Durig DT, Esterle JS, Dickson TJ, Durig JR (1988) An investigation of the chemical variability of woody peat by FT-IR spectroscopy. Appl Spectrosc 42(7):1239-1244

Fellman JB, D'Amore DV, Hood E, Boone RD (2008) Fluorescence characteristics and biodegradability of dissolved organic matter in forest and wetland soils from coastal temperate watersheds in Southeast Alaska. Biogeochemistry $88(2): 169-184$

Freeman C, Ostle NJ, Fenner N, Kang H (2004) A regulatory role for phenol oxidase during decomposition in peatlands. Soil Biol Biochem 36(10):1663-1667

Glatzel S, Kalbitz K, Dalva M, Moore T (2003) Dissolved organic matter properties and their relationship to carbon dioxide efflux from restored peat bogs. Geoderma 113(3-4):397-411

Hergoualc'h Kl, Verchot LV (2011) Stocks and fluxes of carbon associated with land use change in southeast Asian tropical peatlands: a review. Glob Biogeochem Cycles 25:13

Hirano T, Segah H, Harada T, Limin S, June T, Hirata R, Osaki M (2007) Carbon dioxide balance of a tropical peat swamp forest in Kalimantan, Indonesia. Glob Change Biol 13(2):412-425

Hirano T, Jauhiainen J, Inoue T, Takahashi H (2009) Controls on the carbon balance of tropical peatlands. Ecosystems 12(6):873-887

Hoffmann WA, Schroeder W, Jackson RB (2003) Regional feedbacks among fire, climate, and tropical deforestation. J Geophys Res 108:11

Hooijer A (2005) Hydrology of tropical wetland forests: recent research results from Srawak peatswamps. In: Forest, water and people in the humid tropics. UNESCO international hydrology series. Cambridge, Cambridge University Press

Hooijer A, Silvius M, Wosten H, Page S (2006) Assessment of $\mathrm{CO}_{2}$ emissions from drained peatlands in SE Asia. Delft Hydraulics report Q3943. IEA, Delft

Hooijer A, Page S, Canadell JG, Silvius M, Kwadijk J, Wösten H, Jauhiainen J (2010) Current and future $\mathrm{CO}_{2}$ emissions from drained peatlands in southeast Asia. Biogeosciences 7:1505-1514

Ise T, Moorcroft PR (2006) The global-scale temperature and moisture dependencies of soil organic carbon decomposition: an analysis using a mechanistic decomposition model. Biogeochemistry 80(3):217-231

Jauhiainen J, Takahashi H, Heikkinen JEP, Martikainen PJ, Vasander H (2005) Carbon fluxes from a tropical peat swamp forest floor. Glob Change Biol 11(10):1788-1797
Jauhiainen J, Hooijer A, Page SE (2012) Carbon dioxide emissions from an Acacia plantation on peatland in Sumatra, Indonesia. Biogeosciences 9:617-630

Jennings E, Järvinen M, Allott N, Arvola L, Moore K, Naden P, Nic Aonghusa C, Nõges T, Weyhenmeyer GA (2009) Impacts of climate on the flux of dissolved organic carbon from catchments. In: George Glen (ed) The impact of climate change on European lakes. Springer, Dordrecht, pp 199-220

Jones TG, Freeman C, Lloyd A, Mills G (2009) Impacts of elevated atmospheric ozone on peatland below-ground DOC characteristics. Ecol Eng 35(6):971-977

Kalbitz K, Geyer W, Geyer S (1999) Spectroscopic properties of dissolved humic substances, a reflection of land use history in a fen area. Biogeochemistry 47(2):219-238

Kalbitz K, Geyer S, Gehre M (2000) Land use impacts on the isotopic signature (13C, 14C, $15 \mathrm{~N}$ ) of water-soluble fulvic acids in a German Fen area. Soil Sci 165(9):681-758

Kobayashi S (1999) Initial phase of secondary succession in the exploited peat swamp forest (Shorea albida) at Sungai Damit, Belait in Brunei Darussalam. In: Proceedings of the international symposium on tropical peatlands, pp 205-214. ISTP, Bogor, 22-23 November 1999

Kreutzweiser DP, Hazlett PW, Gunn JM (2008) Logging impacts on the biogeochemistry of boreal forest soils and nutrient export to aquatic systems: a review. Environ Rev 16:157-179

Kuhry P, Vitt DH (1996) Fossil carbon/nitrogen ratios as a measure of peat decomposition. Ecology 77(1):271-275

Laiho R (2006) Decomposition in peatlands: reconciling seemingly contrasting results on the impacts of lowered water levels. Soil Biol Biochem 38(8):2011-2024

Maie N, Parish KJ, Watanabe A, Knicker H, Benner R, Abe T, Kaiser K, Jaffé R (2006) Chemical characteristics of dissolved organic nitrogen in an oligotrophic subtropical coastal ecosystem. Geochim Cosmochim Acta 70(17):4491-4506

Malcolm RL (1990) The uniqueness of humic substances in each of soil, stream and marine environments. Anal Chim Acta 232:19-30

Malmer N, Holm E (1984) Variation in the C/N-quotient of peat in relation to decomposition rate and age determination with $210 \mathrm{~Pb}$. Oikos 43(2):171-182

McKnight DM, Boyer EW, Westerhoff PK, Doran PT, Kulbe T, Andersen DT (2001) Spectrofluorometric characterization of dissolved organic matter for indication of precursor organic material and aromaticity. Limnol Oceanogr 46(1):38-48

Miettinen J, Shi C, Liew SC (2011) Deforestation rates in insular Southeast Asia between 2000 and 2010. Glob Change Biol 17(7):2261-2270

Minkkinen K, Byrne KA, Trettin C (2008) Climate impacts of peatland forestry. In: Peatland and climate change. IPS, pp 98-121

Miyamoto E, Matsuda S, Ando H, Kakuda K, Jong F, Watanabe A (2009) Effect of sago palm (Metroxylon Sagu Rottb.) Cultivation on the chemical properties of soil and water in tropical peat soil ecosystem. Nutr Cycl Agroecosyst 85(2):157-167

Moore TR, Clarkson BR (2007) Dissolved organic carbon in New Zealand peatlands. NZ J Mar Freshwat Res 41(1):137-141 
Moore S, Gauci V, Evans CD, Page SE (2011) Fluvial organic carbon losses from a Bornean blackwater river. Biogeosciences 8:901-909

Nieminen M (2004) Export of dissolved organic carbon, nitrogen and phosphorus following clear-cutting of three norway spruce forest growing on drained peatlands in Southern Finland. Silva Fennica 38:2

Page SE, Siegert F, Rieley JO, Boehm HV, Jaya A, Limin S (2002) The amount of carbon released from peat and forest fires in Indonesia during 1997. Nature 420(6911):61-65. doi:10.1038/nature01131

Page SE, Rieley JO, Banks CJ (2011a) Global and regional importance of the tropical peatland carbon pool. Glob Change Biol 17:798-818. doi:10.1111/j.1365-2486.2010. 02279.x

Page SE, Morisson R, Malins C, Hooijer A, Rieley JO, Jauhiainen J (2011b) Review of peat surface greenhouse gas emissions from oil palm plantations in Southeast Asia. ICCT white paper 15. International Council on Clean Transportation, Washington, DC

Porcal P, Koprivnjak J, Molot LA, Dillon PJ (2009) Humic substances-part 7: the biogeochemistry of dissolved organic carbon and its interactions with climate change. Environ Sci Pollut Res 16(6):714-726

Rieley, JO, Wüst RAJ, Jauhiainen J, Page SE, Wösten H, Hooijer A, Siegert J, Limin SH, Vasander H, Stahlhut H (2008) Tropical peatlands: carbon stores, carbon gas emissions and contribution to climate change processes. In: Atarck M (ed) Peatlands and carbon cycle, vol 6. International Peat Society, Quebec, p 224

Rixen T, Antje B, Thomas P, Wolfgang B, Joko S, Christine J (2008) The Siak, a tropical black water river in Central Sumatra on the verge of anoxia. Biogeochemistry 90: 129-140. doi:10.1007/s10533-008-9239-y
Singleton VL, Joseph Rossi A (1965) Colorimetry of total phenolics with phosphomolybdic-phosphotungstic acid reagents. Am J Enol Vitic 16(3):144-158

van der Werf GR, Morton DC, DeFries RS, Olivier JGJ, Kasibhatla PS, Jackson RB, Collatz GJ, Randerson JT (2009) $\mathrm{CO}_{2}$ emissions from forest loss. Nat Geosci 2(11):737-738

Weishaar JL, Aiken GR, Bergamaschi BA, Fram MS, Fujii R, Mopper K (2003) Evaluation of specific ultraviolet absorbance as an indicator of the chemical composition and reactivity of dissolved organic carbon. Environ Sci Technol 37(20):4702-4708

Williams CJ, Yavitt JB, Wieder RK, Cleavitt NL (1998) Cupric oxide oxidation products of northern peat and peat-forming plants. Can J Bot 76(1):51-62

Worrall F, Burt T (2005) Predicting the future DOC flux from upland peat catchments. J Hydrol 300(1-4):126-139

Yamashita Y, Scinto LJ, Maie N, Jaffé R (2010) Dissolved organic matter characteristics across a subtropical wetland's landscape: application of optical properties in the assessment of environmental dynamics. Ecosystems 13:1006-1019

Yanai RD, Currie WS, Goodale CL (2003) Soil carbon dynamics after forest harvest: an ecosystem paradigm reconsidered. Ecosystems 6(3):197-212

Yule C, Gomez L (2009) Leaf litter decomposition in a tropical peat swamp forest in peninsular Malaysia. Wetl Ecol Manag 17(3):231-241

Zaccone C, D’Orazio V, Shotyk W, Miano TM (2009) Chemical and spectroscopic investigation of pore water and aqueous extracts of corresponding peat samples throughout a bog core (Jura Mountains, Switzerland). J Soils Sediments 9:443-456 